Brit. F. vener. Dis. (1969), 45, 334.

\title{
NON-GONOCOCCAL INFECTIONS OF THE FEMALE GENITALIA
}

\author{
BY \\ B. A. TEOKHAROV \\ Department of the Skin and Venereal Diseases, Omsk Medical Institute, U.S.S.R.
}

Non-gonococcal inflammations of the female genitalia are of very common occurrence and many of them correspond to forms of non-gonococcal urethritis in the male. Some authors, including Ilyin (1966), have found various inflammatory processes of the lower urogenital tract in the majority of women who had had sexual contact with men suffering from non-gonococcal urethritis; such women may have vaginitis, cervicitis, urethritis, and other inflammatory changes. Trichomoniasis and candidiasis are the best known of these diseases in women and it is considered that other infections have not received adequate attention.

Before discussing these various conditions it is necessary to classify diseases appearing as the result of infection during sexual intercourse, and to give a definition of "venereal disease".

I call venereal diseases those in which the causative agents are transmitted mainly by sexual contact. So the main determining factor for recognition of a venereal disease is the means of transmission of its causative agent. Sexual transmission of venereal diseases is determined by the characteristics of their causative micro-organisms:

(1) Under natural conditions they can exist only in human beings and the common sites are the genitourinary organs of both sexes, although, as in the case of syphilis, they may subsequently become widespread.

(2) They are very unstable in an unnatural environment.

Both Neisseria gonorrhoeae and Trichomonas vaginalis have these properties and are transmitted sexually. In my opinion all organisms, known and unknown, which have these characteristics are usually transmitted sexually.

There is also another category of diseases which

Received for publication March 4, 1968.

Paper given to the MSSVD on February 26, 1968. may result from infection during sexual intercourse, although their causative agents are usually transmitted in other ways. For instance Candida urethritis may result from contamination during sexual intercourse but the fungus Candida albicans is usually transmitted by other types of contact. I suggest that pathological conditions resulting from such transmission should be called venereal manifestations of non-venereal infections. Their causative agents have different characteristics from those of the micro-organisms of the venereal diseases.

There are thus two categories of diseases appearing through infection during sexual intercourse:

(I) The venereal diseases (or venereal infections) in which the causative agents are transmitted mainly by sexual intercourse;

(II) The venereal forms of non-venereal (or non-sexual) infections in which the causative agents may be transmitted venereally but are usually communicated by other means.

There is a significant practical difference between these two categories. In theory the techniques used for the control of the former could completely eliminate them, but such techniques can have little effect in reducing the incidence of the latter because their complete elimination needs other methods of control.

I. The Venereal Diseases may be subdivided as follows:

(a) Urogenital (gonorrhoea, urogenital trichomoniasis, chlamydozoon blennorrhoea [TRIC agent], Haemophilus vaginalis infection, and blennorrhoea due to mycoplasmata);

(b) Dermatological (syphilis, chancroid, donovanosis, lymphogranuloma venereum, and condylomatosis). 
II. The Venereal Forms of Non-venereal (non-sexual) Infections may be subdivided as follows:

(a) Candida urethritis and balanoposthitis, sometimes vulvo-vaginitis;

(b) Amoebiasis of the genitalia;

(c) Various forms of bacterial urethritis of venereal origin in the male;

(d) Fusospirochaetosis of the genitalia;

(e) Genital herpes and others.

Using this classification we may now divide all inflammatory processes of the lower part of the female genitalia into three groups:

(1) Venereal diseases;

(2) Venereal forms of non-sexual infections;

(3) Non-specific inflammatory conditions, the causes of which are still not clear.

\section{GROUP 1. Venereal Diseases}

1(a) Urogenital Trichomoniasis This is the most common condition. The causative microorganism is Trichomonas vaginalis, which was discovered in the vaginal discharge by Donné (1836). Marchand (1894), Miura (1894), and Dock (1894) were the first investigators to find the parasite in men. It was more than 20 years before Hoehne (1916) claimed that Trichomonas vaginalis was the causative agent of the condition which we now call trichomonas vaginitis, and even then the pathogenicity of Trichomonas vaginalis could not be established because it was not possible at that time to obtain a pure culture of the micro-organism.

Trussell and Plass (1940) obtained pure cultures of Trichomonas vaginalis and were then able completely to prove its pathogenicity. Later Hogue (1943), Schnitzer, Kelly, and Leiwant (1950), Teras (1954), Teokharov (1957), and others studied the pathogenic properties of this protozoon.

Teras (1954) showed that different strains of Trichomonas vaginalis could possess strong, medium, or mild pathogenicity.

On the other hand Teokharov (1957, 1959) ascertained in experimental animals that an exceptionally severe pathological process resulted from simultaneous injection of trichomonads and bacteria, and confirmed these results by clinical observation. The most severe inflammatory process resulting from trichomoniasis occurs in the vagina when abundant bacterial flora are present; it is less severe in the urethra where there are fewer bacteria, and least severe in the prostate gland the fluid of which is usually abacterial.

In earlier years, when the epidemiology of trichomoniasis was not understood, its common occurrence in women was thought to be due to contamination with trichomonads during bathing or through washing the genitalia with cold water. It was believed that there was only one species of trichomonad which could change into this or that variety. Some workers thought that women could be contaminated with trichomonads from animals, and others that trichomonads could enter the vagina from the rectum.

It is now established that Trichomonas vaginalis is an independent species differing from other species of trichomonads and also from flagellates living in water which do not affect the human genitalia.

Many believed that the organisms could form cysts and that they could exist for a long time in an unfavourable environment and produce the disease by accidental contamination of the female genitalia, but it is now accepted that such is not the case.

Capek (1927) was the first to show the possibility of sexual infection with Trichomonas vaginalis, but even when this event was accepted it was considered to be very rare. Because the incidence of trichomoniasis in men was thought to be very much less than in women, many workers thought and still think that the sexual transmission of trichomoniasis cannot alone explain its very frequent occurrence in women. However, Teokharov (1956) and Bauer (1957) showed that it occurs in the male almost as frequently as in the female.

The method of obtaining specimens for the microscopical or cultural examination of trichomonads in men is of paramount importance. We do not use the method of scraping the mucous membrane of the urethra. Trichomonads do not penetrate the subepithelial tissue of the urethra but are situated in the lacunae of Morgagni, especially in the lacuna of Geren. During urethroscopy we obtain the contents of the lacunae of Morgagni by means of an endourethral cannula.

For diagnosis, therefore, we instill two or three drops of normal saline solution (Teokharov, 1956) into the meatus with a pipette and allow them to flow into the distal part of the urethra. Afterwards we massage that part of urethra and remove the fluid for examination. By this method we have found protozoa in 80 to 90 per cent. of the male consorts of women suffering from trichomoniasis, thus establishing that the disease is transmitted sexually.

The non-sexual infection of women is possible but is probably very rare. Trichomonas vaginalis is very sensitive to an unfavourable environment. The data of many authors (Jìrovec and Peter, 1948; Teokharov, 1958; Teras, 1964) show that drying, 
high temperature, or a change in osmotic pressure will quickly kill the organism. It is much more vulnerable to environmental factors than Neisseria gonorrhoeae; for example, trichomonads die in water within 10 to 30 minutes but gonococci may survive for 24 hours or more.

Whittington (1957) and Burgess (1963) investigated the possibility of the transmission of trichomonads from lavatories. It is well known that nonsexual infection with gonorrhoea from public lavatories occurs very rarely in women, and it seems likely that infection with trichomoniasis occurs even more rarely.

We can determine the part that non-sexual infection plays in the epidemiology of a venereal disease by ascertaining (1) the proportion of cases that occur in children and (2) the frequency of primary extragenital localization.

Summarized data of various authors indicate that the number of children infected with gonorrhoea averages 2.67 per cent. of cases, and with trichomoniasis 0.12 per cent. The existence of primary extragenital trichomoniasis is unproven, and extragenital gonorrhoea involving the conjunctiva now occurs very rarely except in the newly born. Thus, this evidence also supports the view that non-sexual contamination with trichomoniasis is more rare than non-sexual infection with gonorrhoea, so that urogenital trichomoniasis is more truly a venereal disease even than gonorrhoea. It is my belief that trichomoniasis is more strictly venereal than any other "venereal" disease, and that the infection of women with trichomoniasis occurs almost always by sexual contact, with very rare exceptions.

The incubation period is from 3 days up to 3 weeks. In the female the trichomonads are found most often in the vagina, then in the urethra, and more rarely in Skene's glands, Bartholin's glands, the cervix, and the bladder. The trichomonads may penetrate as far the body of the uterus and the Fallopian tubes in exceptional cases.

Trichomoniasis can be acute, subacute, or chronic, and the last may be asymptomatic, some patients being carriers of the organism. The pathological process is acute or subacute in about half of the affected women at the onset of trichomonal infestation. The patients complain of abundant purulent discharge with offensive odour, itching, or burning of the external genitalia, and there may be pain or burning on micturition.

Examination of such a patient will show hyperaemia of the vagina and vulva and a purulent yellow-greenish liquid discharge, which may have a frothy appearance owing to the metabolic activity of the trichomonads and concomitant bacterial flora. If the patient has urethritis it is possible to express by massage a whitish or yellowish secretion from the urethra. Abundant purulent discharge can cause irritation on the inner sides of the thighs.

Often the insertion of a speculum into the vagina is painful. The mucous membrane of the vagina is usually all bright red, but sometimes there is a punctate erythematous or "strawberry" appearance or many very small erosions. The cervix may also be involved with the formation of erosions, but endocervicitis is more common in gonorrhoea than in trichomoniasis. If the bladder is involved the patient has frequency of micturition and dysuria.

In chronic cases the symptoms and signs are mild or sometimes absent, but exacerbations are very apt to occur. The disease may persist for many years if untreated.

The diagnosis must be made by demonstrating trichomonads; this may be done by means of microscopical examination of wet or stained smears but the most certain method is to grow the organism in culture. In all cases it is necessary to take specimens not only from the vagina but also from the urethra. I believe it is better to examine wet smears than stained smears because in fresh preparations trichomonads are more easily distinguished from other cells not only by their morphological characteristics but also by the appearance of jerky movements. If stained smears are used it is necessary to apply stains which reveal the morphology of the organism such as Giemsa or Leishman. Staining by methylene blue is unreliable. Mistakes can be made in the recognition of this organism as with that of the gonococcus.

All cases of trichomoniasis including carriers must be treated and the treatment of both sexual partners is obligatory to prevent re-infection.

Oral treatment with metronidazole (Flagyl, Clont, Trichopol) is very effective. We give $250 \mathrm{mg}$. three times daily for the first 2 days and then the same dose twice a day. A total dosage of 3.5 or $4 \mathrm{~g}$. metronidazole is quite enough to effect a cure in the great majority of cases. A combined method of treatment is, however, the most effective. We give metronidazole by mouth and during the same period we insufflate the walls of the vagina with a powder consisting of acetarsol (Spirocid) to which is added a bactericide (chloramphenicol) and a fungicide (Nystatin). In our series of patients treated by this method the relapse rate has been only $6 \cdot 1$ per cent.

1(a) Chlamydozoon Blennorrhoea

Infection with Chlamydozoon (or Chlamydia) 
oculogenitale is another venereal disease that can affect the genitalia. Jones (1964), Dunlop, Jones, and Al-Hussaini (1964), and others consider that the causative agents of this infection of the genitalia, of inclusion conjunctivitis, and of trachoma are probably the same organism-TRIC agent: a member of the Bedsonia group. This infection usually affects the genitalia but it can involve the eyes and perhaps also the joints. The organism is usually transmitted by sexual contact, but a mother can infect her child during delivery, and this type of conjunctivitis may therefore occur in the newly born.

This organism produces endocervicitis and sometimes vaginitis and urethritis with a mucopurulent discharge and a follicular appearance of the inflamed mucous membranes. Erosion of the cervix may appear, and the organism may possibly produce adnexitis.

Some authors (Siboulet and Galistin, 1962; Jodzishsky, 1966; and others) have found cytoplasmic inclusions in epithelial cells from the mucous membrane of the urethra of patients suffering from the urethro-oculo-synovial syndrome (Reiter's disease). Schachter, Barnes, Jones, Engleman, and Meyer (1966) isolated an organism resembling TRIC agent not only from the urethra but also from the joints in patients with Reiter's disease. King and Nicol (1964) and Willcox (1964) believed that many arthritic manifestations observed in the course of an attack of gonorrhoea were symptoms of associated Reiter's disease. Reiter's syndrome occurs mainly in men, but Oates and Csonka (1959) and Shakhova (1961) have shown that it occurs in women also.

Kotcher, Gray, James, Frick, and Bottorff (1962) found TRIC agent infection in 2.8 per cent. of patients seen in obstetric and gynaecological clinics. Probably this infection is more common than the results of diagnostic tests indicate.

In the diagnosis of this disease we examine scrapings of the mucous membranes of the urethra, cervix, or conjunctiva. In Giemsa-stained smears we find the cytoplasmic inclusion bodies in epithelial cells. These inclusions are often arranged in a crescent around the nucleus. Jodzishsky (1966) also suggested an intradermal test with a vaccine of ornithosis because there is cross-immunity between the organism of the virus which can cause ornithosis and Chlamydozoon oculogenitale.

Doubtless the most exact method is the isolation of the organism in the yolk sac of the developing chick embryo. Pukhner (1967), for instance, believes that inclusions in scrapings from the mucous membrane are found in only 10 per cent. of cases of this infection. However, the isolation of organisms of this group is a very complicated technique, and is at present available only in highly specialized laboratories.

Tetracycline by mouth is the most effective remedy. The effective dosage is $200 \mathrm{mg}$. 5 times a day, up to a total of about 10 to $12 \mathrm{~g}$. Antiseptics are useful for local treatment.

\section{1(a) 'Haemophilus' Vaginitis}

Leopold (1953) found in urethritis in men and endocervicitis in women an undescribed pleomorphic Gram-negative rod which seemed related to the genus 'Haemophilus'^. Gardner and Dukes (1954, 1955), who did not know of Leopold's work, found and described what was probably the same organism in cases of non-specific bacterial vaginitis; they called this bacterium 'Haemophilus vaginalis' and claimed that it was the causative agent of a specific vaginitis with a recognizable clinical picture. They found 'Haemophilus vaginalis' in 92 per cent. of patients with so-called non-specific vaginitis and believed that transmission occurred by sexual contact.

Stained smears from the vagina in these cases showed very large numbers of small Gram-negative rods. Döderlein's bacilli were usually absent and leucocytes were present in only very small numbers. Many rods seemed to be attached to epithelial cells giving them a granular appearance in wet smears. Gardner and Dukes called them "clue cells".

On modified blood agar medium (Casman, 1947) there was a growth of very small colonies surrounded by a zone of haemolysis.

At present opinions vary as to the importance of 'Haemophilus vaginalis' in genital infection. Some authors believe it to be pathogenic, others think its pathogenicity is doubtful, and others find no connexion between 'Haemophilus vaginalis' and the presence of disease.

We found 'Haemophilus vaginalis' in the vagina in 21.7 per cent. of our female patients and in the urethra in 9.3 per cent. of males. The organism was associated with pathological changes in the vagina, and many of the patients had a greyish-white discharge with an unpleasant odour. Some had redness and itching, and many complained of increased genital secretion, but most had no evidence of inflammatory reaction. It may nevertheless be true that 'Haemophilus vaginalis' can produce slight vaginitis with or without hypersecretion.

Its presence in men was not associated with signs of disease, so that it is possible that men are carriers

\footnotetext{
$\star$ Zinneman and Turner (1963) later identified this organism as a Corynebacterium, but it is still convenient to retain the original terminology.
} 
of this infection and infect women by sexual contact.

If this condition is present it is necessary to treat both sexual partners. Local tetracycline is effective in women, and men seem to respond to urethral irrigation with a solution of mercury oxycyanide $(1: 6000)$.

\section{1(b) Condylomatosis}

This is the name which is given to genital (or venereal) warts or acuminate condylomata which are caused by a virus. Most dermatologists believe that these are a clinical variety of common warts and are caused by the same virus, but our epidemiological and clinical investigations indicate that condylomatosis is probably an independent disease transmitted mainly by sexual intercourse. Barrett, Silbar, and McGinley (1954), Shabad (1963), and others have expressed the same opinion.

I have only rarely observed acuminate condylomata and common warts occurring in the same patient. On the other hand an examination of the sexual contacts of patients with condylomatosis revealed that two-thirds of them were suffering from the same condition. Electronmicroscopic investigations by Zimmer, Bähnsch, and Grimm (1964) showed some difference between the condylomatous viral particles and the wart virus; the viral particles of the condylomata are smaller and are situated not only in the nucleus but also in the cytoplasm.

Acuminate condylomata in women are mostly situated on the external genitalia; they were found in the vagina in about 20 per cent. of our patients, and the vagina was the only site affected in eleven patients.

The rubbing in of "antiverrucin" powder or painting with podophyllin are both effective methods of treatment, but large condylomata may require surgical intervention.

\section{GROUP 2. Venereal Forms of Non-Sexual Infections}

In women these are mostly caused by the Candida species and the virus of herpes simplex and various bacterial infections.

\section{2(a) Candidiasis (or thrush)}

This condition is of very common occurrence. Candida fungus is very persistent when present in the genital organs and can be transmitted in various ways. Candida balanoposthitis and urethritis usually arise from sexual transmission, but the female genitalia are usually infected in other ways, often from the rectum (Akhmedova, 1965; Rohatiner, 1966). In cases of sexual transmission the patient may be said to have a venereal form of non-sexual infection. Familial candidiasis is often observed.

Candida (usually Candida albicans) can cause vulvitis and vaginitis. It may also affect the cervix and urethra but this is rare. The patients may complain of external itching or burning, and there is redness of the mucous membrane of the vulva and vagina with a greyish-white cheesy discharge. Thrush is more common during pregnancy.

However, even when the strain is pathogenic, Candida frequently gives rise to no symptoms, but diabetes or treatment with antibiotics may change the carrier state to that of an active pathological process.

The diagnosis of vaginal thrush is based on the characteristic clinical picture and on the finding of the fungus in smears.

Treatment is by vaginal pessaries or powder containing about 100,000 units of Nystatin. This drug can also be given orally.

\section{2(e) Herpes simplex}

The virus responsible for this condition is usually transmitted non-sexually, but Levaditi and Nicolau (1923) and Mariani (1924) proved experimentally that genital herpes is usually acquired by sexual contact. The virus can remain latent until some mechanical or other irritation causes a relapse of the herpetic eruption.

Eruptions of genital herpes are usually situated on the external genitalia, but are sometimes found on the walls of the vagina or on the cervix and produce a discharge. The virus may be seen in vesicles by electronmicroscopic examination. Local treatment with interferon ointment is effective in some cases.

\section{GROUP 3. Non-specific Inflammations}

Various bacterial infections can be transmitted venereally by sexual contact, but most non-specific bacterial diseases of the female genitalia are probably acquired non-sexually. It is very difficult to find out the species of a causative agent because there is usually an abundant mixed bacterial flora. So-called non-specific vaginitis, endocervicitis, and urethritis are best classified in this third group, but further investigation is needed to determine their cause.

\section{Summary}

The diseases resulting from infection during sexual intercourse are divided into two main groups: (1) The venereal diseases, in which the 
causative agents are transmitted mainly by sexual intercourse; and (2) the venereal forms of nonvenereal (non-sexual) infection in which the causative agents may be transmitted venereally but are usually communicated by other means.

The first group includes gonorrhoea, trichomoniasis, infections due to TRIC agent, and those due to mycoplasmata and to Haemophilus vaginalis.

The second group includes Candida infections, various bacterial infections, fusospirochaetosis, genital herpes, and amoebiasis of the genitalia.

Trichomoniasis is the most common condition in the first group. This diagnosis may be confirmed in men by instilling two or three drops of normal saline solution into the external urinary meatus with a pipette, massaging the urethra, and recovering the fluid for examination. By this method protozoa were found in 80 to 90 per cent. of the male consorts of women suffering from trichomoniasis. The most severe effects of trichomoniasis in women are found when abundant bacterial flora are present in the vagina.

Some of the literature of the conditions enumerated is summarized with a description of the clinical appearances, the diagnostic procedures, and the methods of treatment which have been found effective.

\section{REFERENCES}

Akhmedova, K. H. (1965). Vestn. Derm. Vener., 39, No. 6, p. 55.

Barrett, T. J., Silbar, J. D., and McGinley, J. P. (1954). F. Amer. med. Ass., 154, 333.

BAUER, H. (1957). In "Les infestations à trichomonas. Premier Symposium Européen, Reims, 1957" (Société Française de Gynécologie), p. 21. Masson, Paris.

BuRgess, J. A. (1963). Brit. f. vener. Dis., 39, 248.

CAPEK, A. (1927). Med. Klin., 23, 1535.

Casman, E. P. (1947). Amer. F. clin. Path., 17, 281.

Dock, G. (1894). Med. News (N.Y.), 65, 690.

Donne, A. (1836). C.R. Acad. Sci. (Paris), 3, 385.

Dunlop, E. M. C., Jones, B. R., and Al-Hussaini, M. K. (1964). Brit. F. vener. Dis., 40, 33.

GARDNER, H. L., and DuKES, C. D. (1954). Science, 120, 853.

-,- (1955). Amer. F. Obstet. Gynec., 69, 962.

HOEHNE, O. (1916). Zbl. Gynäk., 40, 4.

Hogue, M. J. (1943). Amer. F. Hyg., 37, 142.

ILYIN, I. I. (1966). "Present Problems of Non-Gonococcal Urethritis of Venereal Origin in the Male" (in Russian). Thesis, Leningrad.

Jirovec, O., and Peter, R. (1948). Schweiz. Z. Path., $11,146$.

JodzishSKy, I. A. (1966). Urol. Nefrol. (Moscow), 1, 36. JONES, B. R. (1964). Brit. f. vener. Dis., 40, 3.
KING, A., and Nicol, C. (1964). "Venereal Diseases". Cassell, London.

Kotcher, E., Gray, A., James, Q. C., Frick, C. A., and BotToRfF, D. W. (1962). Ann. N.Y. Acad. Sci., 97, 571.

LeOpold, S. (1953). U.S. armed Forces med. F., 4, 263.

Levaditi, C., and Nicolau, S. (1923). Ann. Inst. Pasteur., 37, 1 (cited by Lipschütz, 1932).

LIPSCHÜTZ, B. (1932). In "Handbuch der Haut- und Geschlechtskrankheiten", ed. J. Jadassohn, vol. 2, p. 134. Springer, Berlin.

MARChAND, F. (1894). Zbl. Bakt., 15, 709.

Mariani, G. (1924). Arch. Derm. Syph. (Berl.), 147, 259 (cited by Lipschütz, 1932).

MIURA, R. (1894). Zbl. Bakt., 16, 67.

OAtes, J. K., and CsonkA, G. W. (1959). Ann. rheum. Dis., 18, 37.

Pukrnner, A. F. (1967). Vestn. Derm. Vener., 41, No. 5, p. 51.

Rohatiner, J. J. (1966). Brit. f. vener. Dis., 42, 197.

SCHACHTER, J., BARNES, M. G., JoNES, J. P., ENGLEMAN, E. P., and MeYer, K. F. (1966). Proc. Soc. exp. Biol. (N.Y.), 122, 283.

Schnitzer, R. J., Kelity, D. R., and Leiwant, B. (1950). F. Parasit., 36, 343.

Shabad, A. L. (1963). Vestn. Derm. Vener., 37, No. 9, p. 53.

Shakhova, F. B. (1961). "Clinical Reiter's Syndrome in the Female" (in Russian). Thesis, Kharkov.

Siboulet, A., and Galistin, P. (1962). Brit. F. vener. Dis., 38, 209.

Teokharov, B. A. (1956). Vestn. Derm. Vener., 30, No. 5 , p. 49.

- (1957). In "Trudi Omskogo Medicinckogo Instituta", 21, p. 284. Omsk.

- (1958). Vestn. Derm. Vener., 32, No. 5, p. 53.

- (1959). "Epidemiology of Urogenital Trichomoniasis and Problems of Pathogenicity of Vaginal Trichomonads" (in Russian). Thesis, Leningrad.

TERAS. J. H. (1954). "Experimental Investigation of the Pathogenicity of Trichomonas vaginalis" (in Russian). Thesis, Tartu.

- (1964). "Diagnosis, Epidemiology, and Treatment of Urogenital Trichomoniasis" (in Russian). Thesis, Tallin.

Trussell, R. E., and Plass, E. D. (1940). Amer. f. Obstet. Gynec., 40, 883.

Whittington, M. J. (1957). Brit. F. vener. Dis., 33, 80.

WILlcox, R. R. (1964). "Textbook of Venereal Diseases and Treponematoses". Heinemann, London.

ZiMMER, S., BÄHNSCH, R., and GRIMM, C. (1964). Derm. Wschr., 149, 490.

Zinneman, K., and Turner, G. C. (1963). F. Path. Bact. 85, 213.

Les infections non gonococciques des organes génitaux féminins SOMMAIRE

Les maladies dues à une infection contractée pendant un rapport sexuel sont divisées en deux groupes principaux: 
(1) Les maladies vénériennes, dont les agents responsables sont transmis principalement par rapport sexuel;

(2) Les formes vénériennes de l'infection non vénérienne (non-sexuelle), dont les agents responsables peuvent être transmis à l'occasion d'un contact vénérien mais qui sont habituellement contractées d'une autre manière.

Le premier groupe comprend la gonococcie, la trichomonase, les infections dues à l'agent TRIC, et celles dues aux mycoplasmes et à l'Haemophilus vaginalis.

Le deuxième groupe comprend les infections à Candida, les infections à diverses bactéries, la fusospirillose, l'herpès genital et l'amibiase des voies génitales.
La trichomonase est l'état le plus commun dans le premier groupe. Son diagnostic peut être confirmé chez l'homme par l'examen de la sécrétion obtenue après instillation de deux ou trois gouttes de solution salée physiologique dans le méat à la pipette, suivie de massage de l'urètre. Par cette méthode, les protozoaires furent trouvés chez 80 à 90 pour cent des partenaires masculins de femmes atteintes de trichomonase. Les effets les plus sévères de la trichomonase chez les femmes sont rencontrées quand un flore bactérienne abondante est présente dans le vagin.

Quelques publications sur les états mentionnés sont résumées avec une description des aspects cliniques, des procédés de diagnostic et des méthodes de traitement qui ont été trouvés efficaces.

\section{BOOK REVIEW}

The Field Worker in Immigrant Health. Edited by J. S. Dodge. 1969. Pp. 185, 7 figs, index. Staples Press, London. (50s.)

The editor, who is also the major contributor to this book, spent 10 years in Nigeria, where he developed special interests in epidemiology, in population movement, and in the training of field workers; since 1967 he has held the post of Senior Medical Officer in Epidemiology in the Health Department of Bradford. This book is intended as a short guide for health visitors, midwives, and public health inspectors working in British towns in which new communities of immigrants have settled in the past two decades. It will also be of interest and value to teachers and welfare workers directly involved in the relevant problems which must often arise as recently arrived immigrants attempt to adjust to their new environment.

'The book is very readable, has a short glossary, a useful list of books and pamphlets for additional reading, and five appendices. It brings out the many difficulties which may arise from the differences in culture, custom, religion, and diet, and the additional problem of communication which faces the public health and welfare worker in trying to help the non-English-speaking immigrants.

The chapter on venereal diseases is factually sound. It records the few legislative attempts used in the past to control V.D. and outlines the emphasis placed on contact tracing by the Ministry of Health's Memorandum of November, 1968.

All the contributors manifestly approach their tasks with sympathetic understanding of the immigrants' many difficulties. Although the book neither records nor implies it, the reader easily recognizes the heavy burden which faces the staffs of public health, welfare, and educational departments in the areas where immigrant populations have settled.
S. M. LAIRD

\section{NEW PUBLICATION DATES}

Starting in February 1970 the British fournal of Venereal Diseases will be published six times a year, in February, April, June, August, October, and December.

Further particulars, including revised subscription rates, are given in the Notice to Subscribers side the front cover. 